\title{
Acute epiglottitis with intramural oesophageal dissection
}

\author{
Léa Didier, ${ }^{1}$ Thomas Madelaine, ${ }^{2}$ Martin Cour, ${ }^{3}$ Laurent Argaud $^{2}$
}

${ }^{1}$ Réanimation Médicale Groupement Hospitalier Edouard Herriot, Lyon France, Hôpital Edouard Herriot, Lyon, France

${ }^{2}$ Réanimation Médicale, Groupement Hospitalier Edouard Herriot, Lyon, France ${ }^{3}$ Hospices Civils de Lyon, Lyon, France

\section{Correspondence to}

Professor Laurent Argaud, laurent.argaud@chu-lyon.fr

Accepted 14 February 2018

\section{DESCRIPTION}

A woman aged 31 years with no medical history was admitted to the intensive care unit for acute epiglottitis. For 4 days, she had been complaining of fever, intractable vomiting and increasing cervical pain treated with anti-inflammatory drugs.

The admission CT scan confirmed the diagnosis of acute epiglottitis associated with a parapharyngeal abscess (figure 1A). An intramural oesophageal dissection (IOD) was incidentally diagnosed (figure 1B), extending from the upper oesophageal sphincter to the lesser gastric curvature without any sign of mediastinitis (figure $1 \mathrm{C}$ and D). Initial panendoscopy revealed mucosal necrosis on the cervical oesophagus. Neither endoscopy nor an oral contrast-enhanced CT scan revealed any perforation. The parapharyngeal abscess was surgically drained and bacteriological culture revealed Streptococcus anginosus and anaerobic bacteria. A conservative treatment of the oesophagus proved

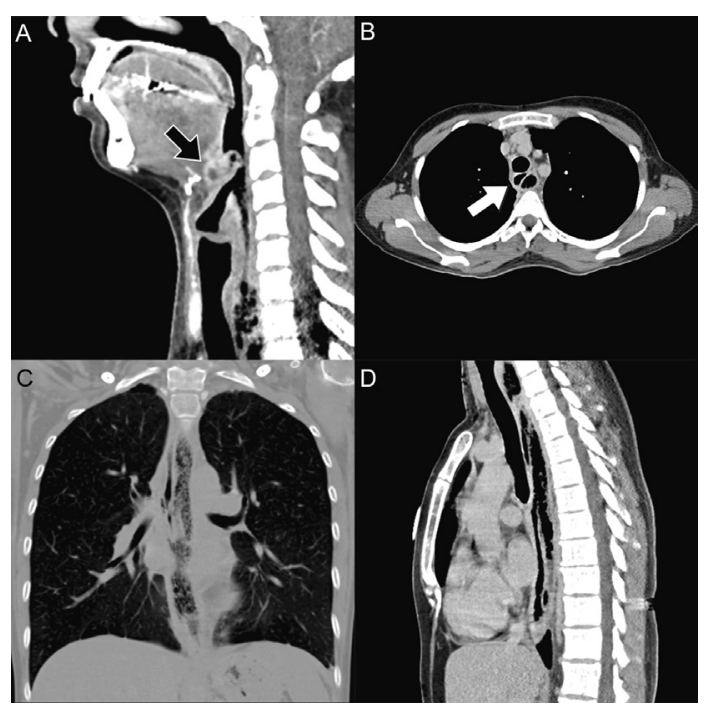

Figure 1 Cervical and thoracic contrast-enhanced CT scan. Acute epiglottitis was associated with a parapharyngeal abscess (panel A, black arrow) and a pneumatic false lumen revealing an extensive intramural oesophageal dissection (panel B, white arrow). The oesophageal dissection extended from the upper oesophageal sphincter to the lesser gastric curvature (panels C and D). No signs of mediastinitis or cellulitis were observed. effective with invasive mechanical ventilation, parenteral nutrition and appropriate antibiotherapy for 15 days. The patient was discharged home 21 days later after normalisation of both endoscopic and radiologic controls.

The present case describes an original presentation of IOD with a pneumatic false lumen complicating severe vomiting in a context of acute epiglottitis. IOD may have also been favoured by epiglottitis-induced local inflammation associated with the use of non-steroidal anti-inflammatory drugs. ${ }^{1}$ Although rare, IODs usually result in dissecting hematomas, caused by sudden pressure changes or direct traumatisms in elderly patients with comorbidities. ${ }^{2}$ Complications of IOD are rare and hence conservative management is the mainstay of treatment unless transmural perforation occurs. ${ }^{3}$

In summary, acute epiglottitis associated with intractable vomiting should lead to a search for IOD to adapt the monitoring.

\section{Learning points}

Epiglottitis may induce intractable vomiting.

- Intramural oesophageal dissection should be searched in this context.

- Conservative management can be considered.

Contributors LD, TM, MC and LA conceived the idea for this manuscript. TM and LA made and selected images. LD, TM and LA wrote the manuscript. MC critically revised the manuscript. LA was responsible for the overall content as guarantor.

Funding This research received no specific grant from any funding agency in the public, commercial or not-for-profit sectors.

Competing interests None declared.

Patient consent Obtained.

Provenance and peer review Not commissioned; externally peer reviewed.

(c) BMJ Publishing Group Ltd (unless otherwise stated in the text of the article) 2018. All rights reserved. No commercial use is permitted unless otherwise expressly granted.

\section{REFERENCES}

1 Chroboczek T, Cour M, Hernu R, et al. Long-term outcome of critically ill adult patients with acute epiglottitis. PLoS One 2015; 10:e0125736.

2 Beumer JD, Devitt PG, Thompson SK. Intramural oesophageal dissection. ANZ J Surg 2010;80:91-5.

3 Mizumoto R, Van Rooyen H. Case report: intramural oesophageal dissection as an usual presentation of chest pain. Ann Med Surg 2015;4:376-9. 
Copyright 2018 BMJ Publishing Group. All rights reserved. For permission to reuse any of this content visit http://group.bmj.com/group/rights-licensing/permissions.

BMJ Case Report Fellows may re-use this article for personal use and teaching without any further permission.

Become a Fellow of BMJ Case Reports today and you can:

- Submit as many cases as you like

- Enjoy fast sympathetic peer review and rapid publication of accepted articles

Access all the published articles

- Re-use any of the published material for personal use and teaching without further permission

For information on Institutional Fellowships contact consortiasales@bmjgroup.com

Visit casereports.bmj.com for more articles like this and to become a Fellow 